\title{
Morphometric and molecular analyses of the composition of potato cyst nematodes carried out by the State Plant Health and Seed Inspection Service during the years 2009-2013
}

\section{Wyniki badań składu gatunkowego mątwików tworzących cysty na ziemniaku prowadzonych przez Państwową Inspekcję Ochrony Roślin i Nasiennictwa w latach 2009-2013 z zastosowaniem metody morfologiczno-metrycznej oraz testów molekularnych}

\author{
Witold Karnkowski ${ }^{1 *}$, Janina Butrymowicz ${ }^{1}$, Marta Saldat ${ }^{1}$, Agata Kaczmarek ${ }^{2}$
}

\section{Summary}

Laboratories of the State Plant Health and Seed Inspection Service to assess the occurrence of the Potato Cyst Nematodes (Globodera rostochiensis and G. pallida) over the period 2009-2013, analysed 213,161 soil samples taken from fields on Polish territory. Viable cysts (ie. containing living eggs and juveniles) from Globodera genus were extracted from 951 soil samples (0.45\%). The results of identification of cysts detected in 584 samples $(61.41 \%)$ were verified using molecular methods. These cysts were preliminary identified to species G. rostochiensis - 547 samples, G. artemisiae - 35 samples and a mixture of two species G. rostochiensis and G. pallida in 1 sample, based on morphometric characters. The result of identification of cysts in one sample was vague. Molecular tests confirmed the results of identification based on morphometric characters. Similarly one of the tested cyst samples where identification results were unclear was finally identified by molecular tests to $G$. pallida. In addition, cysts detected in the soil attached to two samples of table potatoes originating from Cyprus, were identified to G. rostochiensis and G. pallida species by morphometric characters and with molecular tests.

Key words: Globodera rostochiensis; Globodera pallida; Globodera artemisiae; Poland; quarantine pest

\section{Streszczenie}

Laboratoria Państwowej Inspekcji Ochrony Roślin i Nasiennictwa w celu dokonania oceny występowania mątwików tworzących cysty na ziemniaku - Globodera rostochiensis i G. pallida, w latach 2009-2013, poddały analizom 213161 próbek gleby pobranych z pól na terenie Polski. Cysty z rodzaju Globodera z żywą zawartością (tj. zawierające jaja i/lub osobniki młodociane) wyizolowano z 951 próbek $(0,45 \%)$. Wyniki identyfikacji cyst wyizolowanych z 584 próbek $(61,41 \%)$ potwierdzono z użyciem testów molekularnych. Cysty te wstępnie zidentyfikowano, z zastosowaniem metody mikroskopowej (morfologiczno-metrycznej), do gatunku G. rostochiensis - 547 próbek, G. artemisiae - 35 próbek oraz G. rostochiensis i G. pallida razem w 1 próbce. W jednym przypadku wynik identyfikacji na podstawie morfologii cyst był niejednoznaczny. Wyniki badań z zastosowaniem metod molekularnych potwierdziły wyniki identyfikacji morfometrycznej. W jednej próbce wynik identyfikacji morfometrycznej był niejednoznaczny, cysty ostatecznie zidentyfikowano do gatunku G. pallida. Ponadto identyfikacji z zastosowaniem metody morfologiczno-metrycznej oraz testów molekularnych poddano cysty wyizolowane z gleby osypanej z dwóch próbek ziemniaków jadalnych pochodzących z Cypru, identyfikując nicienie z obu próbek do gatunków G. rostochiensis i G. pallida.

Słowa kluczowe: Globodera rostochiensis; Globodera pallida; Globodera artemisiae; Polska; organizm kwarantannowy

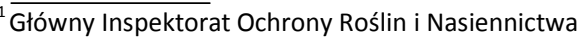
Centralne Laboratorium

Żwirki i Wigury 73, 87-100 Toruń

${ }^{2}$ The James Hutton Institute, Dundee, DD2 5DA, Szkocja, Wielka Brytania

*corresponding author: cl-tor@piorin.gov.pl
} 


\section{Wstęp / Introduction}

Mątwiki tworzące cysty na ziemniaku, tj. mątwik ziemniaczany, Globodera rostochiensis (Wollenweber, 1923) Skarbilovich, 1959 i mątwik agresywny, Globodera pallida (Stone, 1973) Behrens, 1975, są jednymi z najgroźniejszych pasożytów ziemniaka, które podlegają obowiązkowi zwalczania na mocy rozporządzenia Ministra Rolnictwa i Rozwoju Wsi z dnia 21 lutego 2008 r. w sprawie zapobiegania wprowadzaniu i rozprzestrzenianiu się organizmów kwarantannowych (Dz. U. Nr 46, poz. 272, ze zm.).

Wyniki dotychczasowych badań (Kornobis i Stefan 1991; Karnkowski i wsp. 2012) wykazały, że na terenie Polski dominującym gatunkiem jest mątwik ziemniaczany (G. rostochiensis), a obecność mątwika agresywnego (G. pallida) notowano jedynie sporadycznie. Duża zmienność wewnątrzgatunkowa oraz niewielkie różnice morfologiczne między poszczególnymi gatunkami mątwików powodują, że ich identyfikacja z zastosowaniem techniki mikroskopowej może być utrudniona, a jej wyniki niejednoznaczne. $Z$ tego względu coraz częściej do identyfikacji mątwików wykorzystywane są techniki molekularne.

Celem badań było dokonanie weryfikacji statusu obu gatunków mątwików tworzących cysty na ziemniaku na terenie kraju, ustalenie wiarygodności metody morfologiczno-metrycznej stosowanej do identyfikacji mątwików z rodzaju Globodera oraz określenie konieczności stosowania do rutynowej diagnostyki tych nicieni technik molekularnych.

\section{Materiały i metody / Materials and methods}

Badaniom poddano cysty mątwików z żywą zawartością (tj. zawierające jaja lub osobniki młodociane), wyizolowane $\mathrm{z}$ próbek gleby pobranych na terenie całego kraju przez inspektorów Państwowej Inspekcji Ochrony Roślin i Nasiennictwa (PIORiN) w ramach urzędowej kontroli pól uprawnych. W pierwszej kolejności dokonano identyfikacji gatunków na podstawie szczegółowej analizy diagnostycznych cech morfologicznych i morfometrycznych wyizolowanych cyst oraz znajdujących się w cystach osobników młodocianych w oparciu o dane literaturowe (Brzeski 1998; Karnkowski 2006; OEPP/EPPO 2009; OEPP/EPPO 2013).

W kolejnym etapie, przynależność nicieni do gatunków G. rostochiensis lub G. pallida badano z zastosowaniem testu multiplex PCR (Polymerase Chain Reaction - reakcja łańcuchowa polimerazy) według Bulmana i Marshalla (1997), przy użyciu starterów ITS5, PITSr3 oraz PITSp4. Badaniom tym poddano cysty o cechach morfologicznych gatunku G. rostochiensis, w przypadku określonego procentu ich wykryć, a ponadto cysty o typowych cechach morfologicznych gatunków $G$. pallida i G. artemisiae oraz te, których jednoznaczna identyfikacja metodą morfologiczno-metryczną nie była możliwa (100\% przypadków). Gatunek $G$. artemisiae rozwija się przede wszystkim na bylicy pospolitej (Artemisia vulgaris), a nie poraża ziemniaków (Brzeski 1998; Dobosz i wsp. 2013). Do potwierdzania wyniku identyfikacji G. pallida, przeprowadzono dodatkowo test PCR według Zouhara i wsp.
(2000), z użyciem starterów UNI, GRO1, GPA oraz test PCR-RFLP (Polymerase Chain Reaction-Restriction Fragment Length Polymorphism - reakcja łańcuchowa polimerazy-polimorfizm długości fragmentów restrykcyjnych) według Thiéry i Mugniéry (1996) z zastosowaniem starterów $18 \mathrm{~S}$ oraz $26 \mathrm{~S}$ i endonukleazy restrykcyjnej Bsh1236I. O ile wykluczono przynależność nicieni do gatunków $G$. rostochiensis i $G$. pallida, przeprowadzono ich dalszą identyfikację do gatunku $G$. artemisiae, z zastosowaniem testu PCR-RFLP opracowanego i zwalidowanego przez Laboratoire de la Santé des Végétaux, w Le Rheu (Francja) w oparciu o pracę Thiéry i Mugniéry (1996). Zawarta w tej pracy oryginalna metodyka, opracowana do identyfikacji nicieni do gatunków G. rostochiensis i $G$. pallida okazała się również przydatna do identyfikacji gatunku $G$. artemisiae. Nie wiązało się to ze zmianami ani modyfikacjami $\mathrm{w}$ oryginalnej procedurze. Powyższe dane znajdują się tylko w dokumentacji wewnętrznej wspomnianego laboratorium i nie zostały, jak dotąd opublikowane.

Ponadto w pierwszym przypadku wykrycia gatunku G. pallida w gruncie, wyizolowane DNA poddano sekwencjonowaniu w Międzyzakładowej Pracowni Biologii Molekularnej Instytutu Ochrony Roślin - Państwowego Instytutu Badawczego w Poznaniu (Karnkowski i wsp. 2012).

Dalszej diagnostyce z zastosowaniem testów molekularnych, wliczając $w$ to sekwencjonowanie wyizolowanego DNA, poddano także cysty wyizolowane z gleby osypanej z dwóch przesyłek ziemniaków jadalnych pochodzących z Cypru (Karnkowski i wsp. 2011).

\section{Wyniki i dyskusja / Results and discussion}

W publikacji przedstawiono wyniki badań składu gatunkowego mątwików z rodzaju Globodera, ze szczególnym uwzględnieniem gatunków tworzących cysty na ziemniaku z zastosowaniem równolegle dwóch metod: metody mikroskopowej (morfologiczno-metrycznej) i metody molekularnej, przeprowadzonych przez laboratoria PIORiN w latach 2009-2013.

Wykonując badania na obecność mątwików tworzących cysty na ziemniaku przebadano łącznie 213161 próbek gleby. Obecność cyst Globodera spp. z zastosowaniem metody mikroskopowej (morfologiczno-metrycznej), stwierdzono w 951 próbkach $(0,45 \%)$. Weryfikacji wyników $\mathrm{z}$ zastosowaniem testów molekularnych poddano cysty pochodzące łącznie z 584 próbek $(61,41 \%$ wszystkich próbek, w których stwierdzono obecność cyst Globodera spp.). Materiał ten obejmował:

- 547 próbek, tj. 100\% wykryć w roku 2009 oraz minimum 20\% wykryć w latach 2010-2013 w województwach: kujawsko-pomorskim, pomorskim, wielkopolskim i zachodnio-pomorskim oraz minimum $20 \%$ wykryć w latach 2009-2013 z terenu pozostałych województw, gdzie w pierwszym etapie badań cysty zostały zidentyfikowane na podstawie cech morfologicznych jako G. rostochiensis (rys. 1) - badania o charakterze monitoringowym; 
- 1 próbkę, w której w 2010 r. stwierdzono cysty o cechach morfologicznych zarówno G. pallida (rys. 2), jak i G. rostochiensis;

- 1 próbkę pobraną w 2012 r., gdzie jednoznaczna identyfikacja wyizolowanych cyst metodą morfologicznometryczną nie była możliwa (rys. 3);

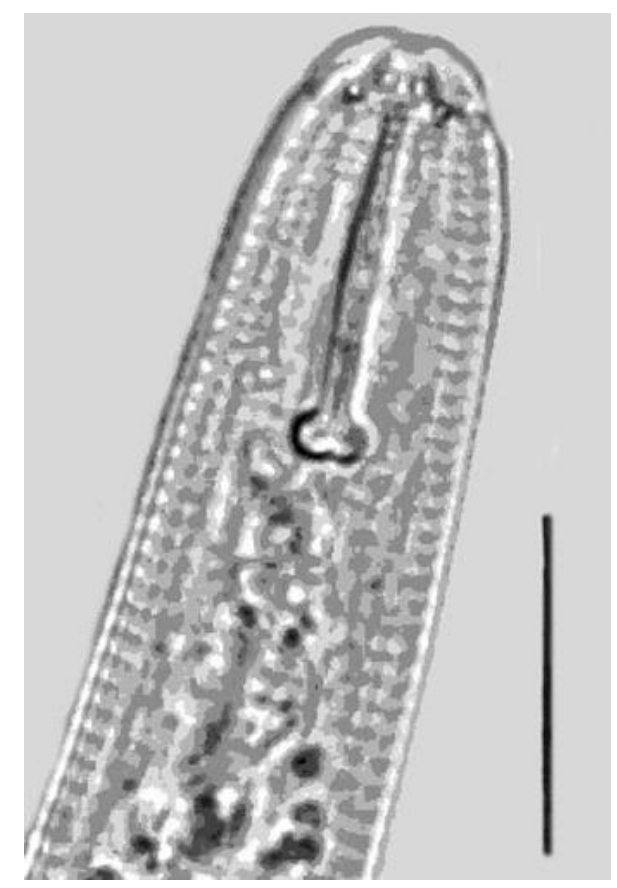

- 35 próbek (tj. 100\%), w których stwierdzono cysty o cechach morfologicznych G. artemisiae.

Ponadto $\mathrm{w}$ dwóch próbkach gleby osypanej $\mathrm{z}$ ziemniaków jadalnych pochodzących $\mathrm{z}$ Cypru stwierdzono cysty o cechach morfologicznych zarówno G. pallida i G. rostochiensis.

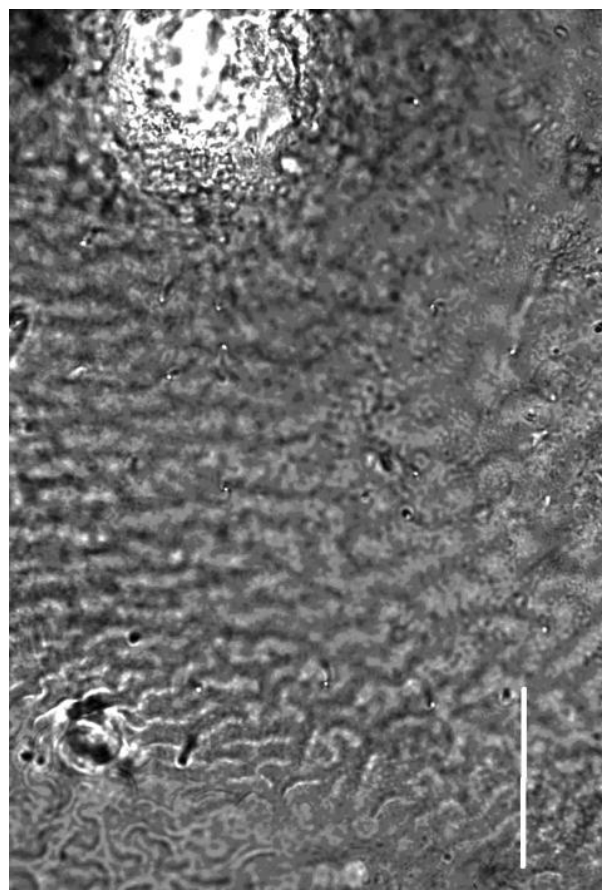

Rys. 1. Przednia część ciała osobnika młodocianego $\mathrm{J}_{2}$ (po lewej; skala wielkości $=20 \mu \mathrm{m}$ ) oraz okolice wulwy i odbytu (po prawej; skala wielkości $=10 \mu \mathrm{m})$ cysty Globodera rostochiensis

Fig. 1. Anterior part of $\mathrm{J}_{2}$ juvenile (left; bar $=20 \mu \mathrm{m}$ ) and the area of fenestra and anus (right; $\left.\mathrm{bar}=10 \mu \mathrm{m}\right)$ of Globodera rostochiensis cyst
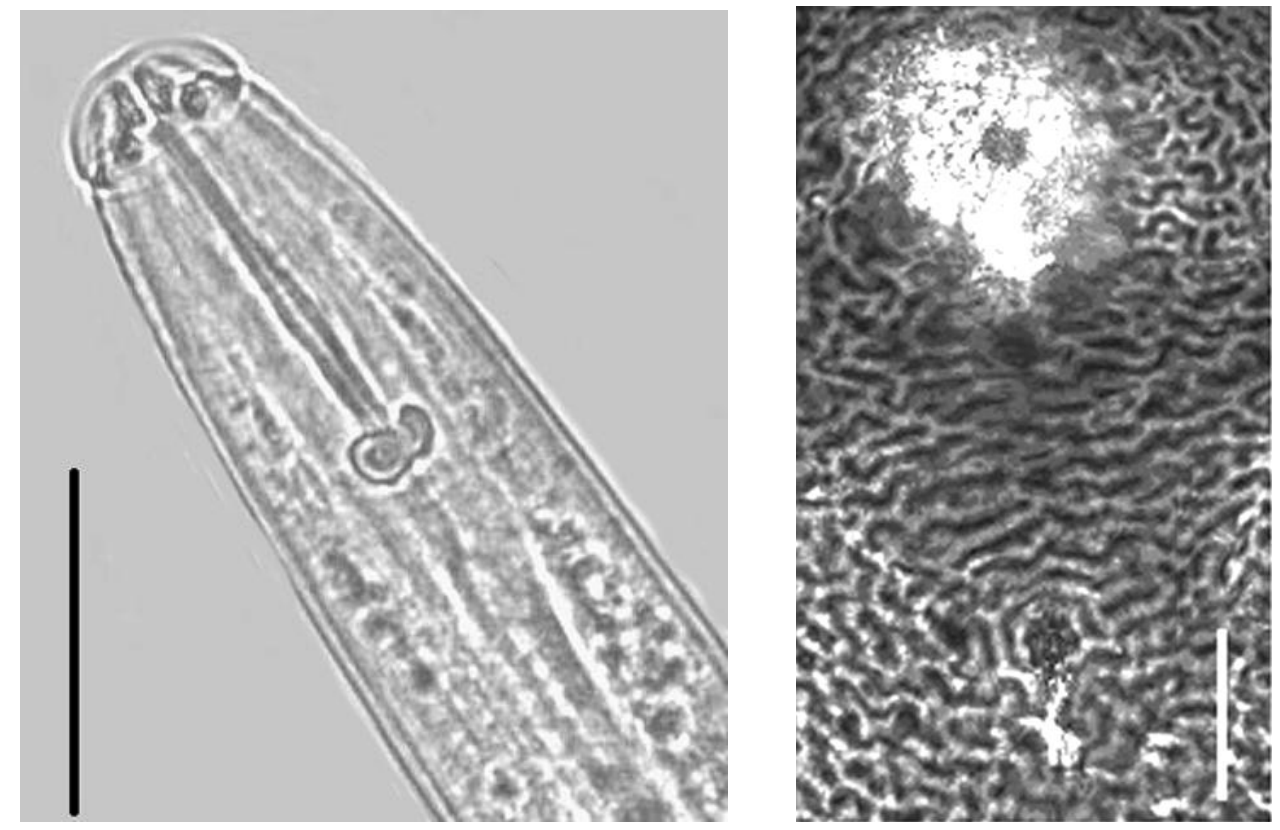

Rys. 2. Przednia część ciała osobnika młodocianego $\mathrm{J}_{2}$ (po lewej; skala wielkości $=20 \mu \mathrm{m}$ ) oraz okolice wulwy i odbytu (po prawej; skala wielkości $=10 \mu \mathrm{m})$ cysty Globodera pallida

Fig. 2. Anterior part of $\mathrm{J}_{2}$ juvenile (left; $b a r=20 \mu \mathrm{m}$ ) and the area of fenestra and anus (right; $b a r=10 \mu \mathrm{m}$ ) of Globodera pallida cyst 

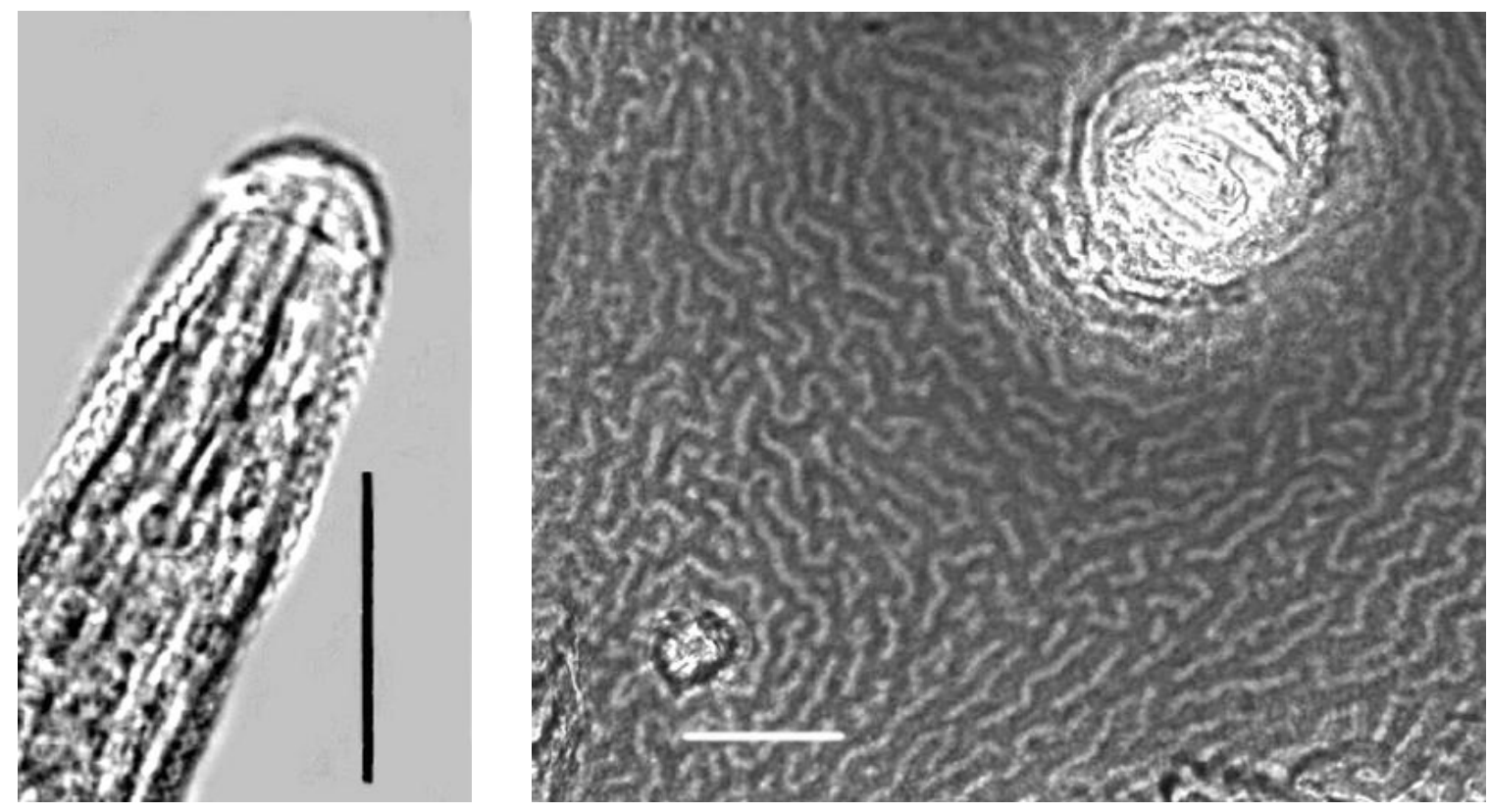

Rys. 3. Przednia część ciała osobnika młodocianego $\mathrm{J}_{2}$ (po lewej; skala wielkości $=20 \mu \mathrm{m}$ ) oraz okolice wulwy i odbytu (po prawej; skala wielkości $=10 \mu \mathrm{m}$ ) cysty, której jednoznaczna identyfikacja na podstawie cech morfologicznych nie była możliwa, a ostatecznie zidentyfikowano je do gatunku Globodera pallida z zastosowaniem testów molekularnych

Fig. 3. Anterior part of $\mathbf{J}_{2}$ juvenile (left; $b a r=20 \mu \mathrm{m}$ ) and the area of fenestra and anus (right; bar $=10 \mu \mathrm{m}$ ) of cyst which unequivocal identification with morphological features was impossible and finally they were identified to Globodera pallida species with molecular tests

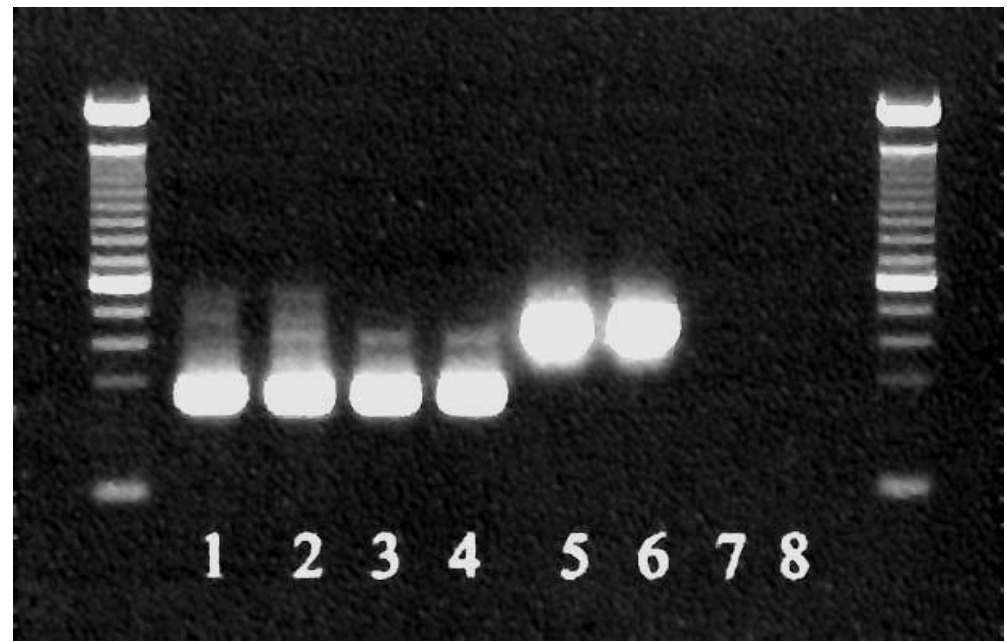

Rys. 4. Rozdział elektroforetyczny produktów reakcji PCR (metoda Bulmana i Marshalla 1997): 1-2 - materiał z badanej próbki: Globodera pallida, 3-4 - kontrola pozytywna dla Globodera pallida, 5-6 - kontrola pozytywna dla Globodera rostochiensis, 7 - kontrola negatywna PCR (kontrola odczynnikowa, bez matrycy DNA); 8 - kontrola negatywna elektroforezy (woda). (użyto marker DNA 100 bp DNA Ladder, Invitrogen); jednoznaczna identyfikacja cyst na podstawie cech morfologicznych nie była możliwa

Fig. 4. PCR profile (method by Bulman and Marshall 1997): 1-2 - material from the tested sample: Globodera pallida, 3-4 - positive control for Globodera pallida, 5-6 - positive control for Globodera rostochiensis, 7 - PCR negative control (reagent control, without DNA template); 8 - electrophoresis negative control (water). DNA marker (100 bp DNA Ladder, Invitrogen) was used; unequivocal identification of cysts with morphological features was impossible

Szczegółowe informacje na temat liczby próbek pochodzenia krajowego (z wykluczeniem materiału pochodzącego z Cypru) poddanych analizie przez poszczególne laboratoria przedstawiono $\mathrm{w}$ tabeli 1 .

Badania metodami molekularnymi potwierdziły we wszystkich przypadkach przynależność gatunkową cyst, wstępnie $\mathrm{z}$ zastosowaniem metody morfologiczno-metrycznej, zaklasyfikowanych do gatunków G. rostochiensis i G. artemisiae (rys. 7) (nie stwierdzono próbek zawierających jednocześnie oba gatunki nicieni) oraz cyst o cechach morfologicznych zarówno G. pallida, jak i G. rostochiensis występujących $\mathrm{w}$ jednej próbce. $\mathrm{W}$ przypadku 


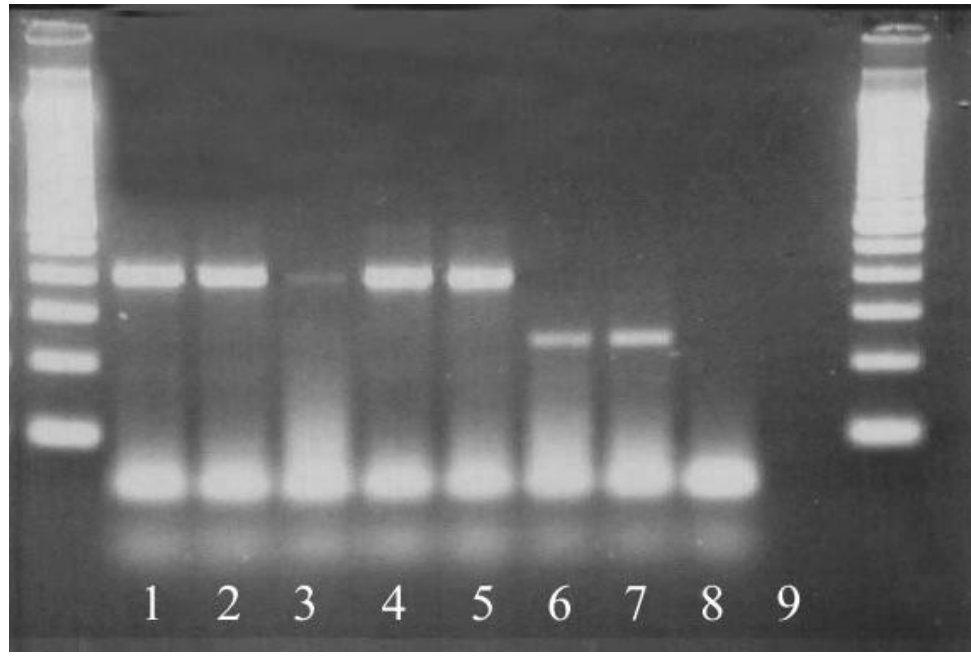

Rys. 5. Rozdział elektroforetyczny produktów reakcji PCR (metoda według Zouhara i wsp. 2000): 1-3 - materiał z badanej próbki: Globodera pallida, 4-5 - kontrola pozytywna dla Globodera pallida, 6-7 - kontrola pozytywna dla Globodera rostochiensis, 8 - kontrola negatywna PCR (kontrola odczynnikowa, bez matrycy DNA), 9 - kontrola negatywna elektroforezy (woda). Użyto marker DNA (100 bp DNA Ladder, Invitrogen); jednoznaczna identyfikacja cyst na podstawie cech morfologicznych nie była możliwa

Fig. 5. PCR products profile (method by Zouhar et al. 2000) observed in the agarose gel electrophoresis: 1-3 - material from the tested sample - Globodera pallida, 4-5 - positive control for Globodera pallida, 6-7 - positive control for Globodera rostochiensis, 8 - PCR negative control (reagent control, without DNA template), 9 - electrophoresis negative control (water). DNA marker (100 bp DNA Ladder, Invitrogen) was used; unequivocal identification with morphological features was impossible

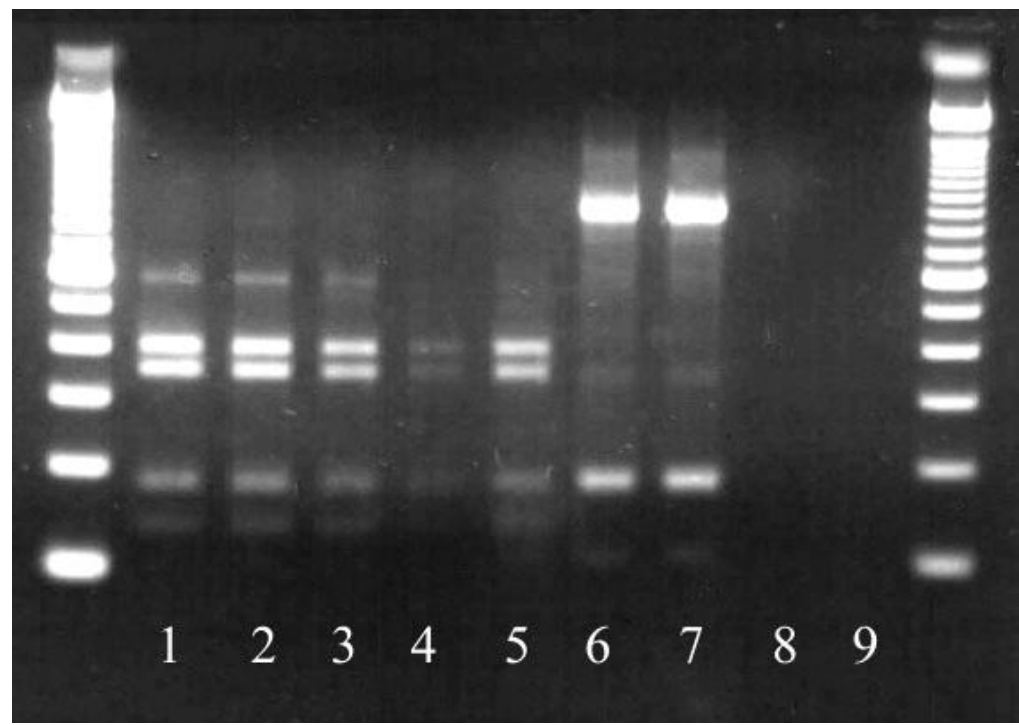

Rys. 6. Rozdział elektroforetyczny produktów reakcji RFLP trawionych enzymem Bsh1236I (metoda według Thiéry i Mugniéry 1996): 1-3 - materiał z badanej próbki: Globodera pallida, 4-5 - pozytywna kontrola trawienia dla Globodera pallida, 6-7 pozytywna kontrola trawienia dla Globodera rostochiensis, 8 - kontrola negatywna PCR (kontrola odczynnikowa, bez matrycy DNA), 9 - kontrola negatywna elektroforezy (woda). Użyto marker DNA (100 bp DNA Ladder, Invitrogen); jednoznaczna identyfikacja cyst na podstawie cech morfologicznych nie była możliwa

Fig. 6. Amplified PCR products from the sample digested by enzyme Bsh1236I (method by PCR-RFLP by Thiéry and Mugniéry 1996): 1-3-material from the tested sample - Globodera pallida, 4-5 - positive digestion control control for Globodera pallida, 6-7 positive digestion control for Globodera rostochiensis, 8 - PCR negative control (reagent control, without DNA template); 9 - electrophoresis negative control (water). DNA marker (100 bp DNA Ladder, Invitrogen) was used; unequivocal identification with morphological features was impossible

gatunków $G$. rostochiensis oraz G. pallida uzyskano produkty reakcji PCR według Bulmana i Marshalla (1997) oraz według Zouharai wsp. (2000). Dla gatunku G. pallida po zastosowaniu trawienia restrykcyjnego enzymem $B s h 1236$ I uzyskano produkty reakcji PCR-RFLP również na wysokości zgodnej z danymi literaturowymi. W przypadku wykryć gatunku G. artemisiae, po zastosowaniu trawienia restrykcyjnego tym samym enzymem, uzyskano produkty reakcji PCR-RFLP na wysokości $\sim 860, \sim 540$, $\sim 320, \sim 190 \mathrm{i} \sim 110 \mathrm{pz}$ (rys. 7). 


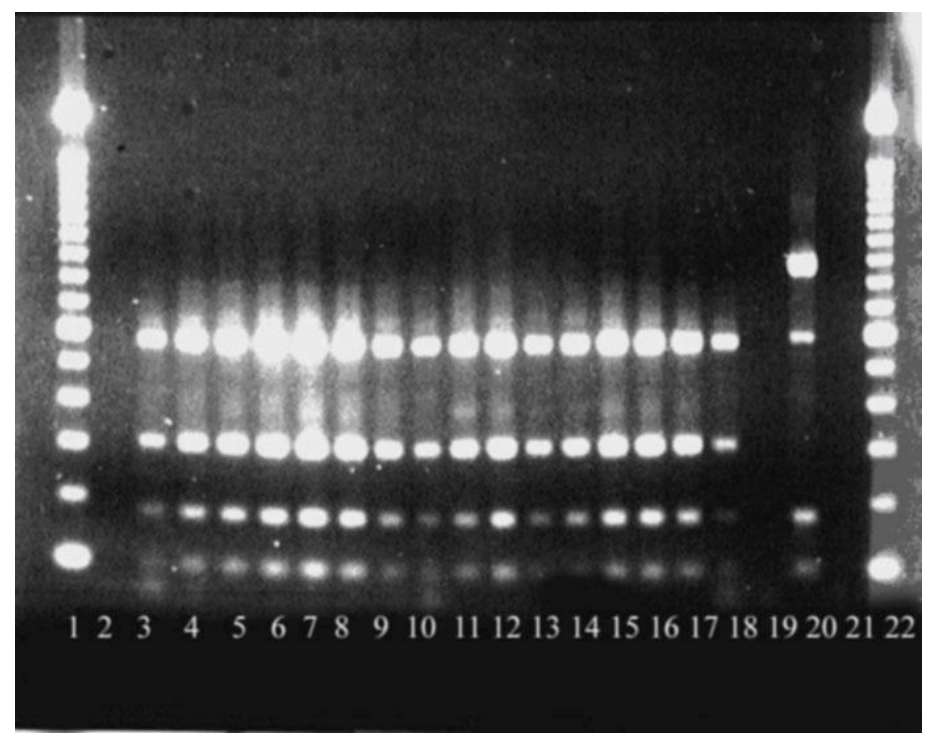

Rys. 7. Rozdział elektroforetyczny produktów reakcji RFLP trawionych enzymem Bsh1236I (według Thiéry i Mugniéry 1996): 2 - materiał z badanej próbki: brak produktu, 3-18 - materiał z badanej próbki: Globodera artemisiae (wzór ułożenia prążków dla typowych cyst), 19 - pozytywna kontrola trawienia dla Globodera pallida (brak produktu), 20 - pozytywna kontrola trawienia dla Globodera rostochiensis, 21 - kontrola negatywna PCR (kontrola odczynnikowa, bez matrycy DNA); 1, 22 marker DNA (100 bp DNA Ladder, Invitrogen)

Fig. 7. Amplified PCR products from the sample digested by enzyme Bsh1236I (PCR-RFLP by Thiéry and Mugniéry 1996): 2 - material from the tested sample: no product, 3-18 - material from the tested sample: Globodera artemisiae (pattern for typical cysts), 19 - positive digestion control control for Globodera pallida (no product), 20 - positive digestion control for Globodera rostochiensis, 21 - PCR negative control (reagent control, without DNA template); 1, 22 - DNA marker (100 bp DNA Ladder, Invitrogen)

Tabela 1. Wyniki badań uzyskane przez poszczególne laboratoria uczestniczące w badaniach próbek pochodzenia krajowego Table 1. Results of tests obtained by particular laboratories participating in the survey of samples originating from Polish territory

\begin{tabular}{|c|c|c|c|c|c|}
\hline \multirow{2}{*}{$\begin{array}{c}\text { Laboratorium } \\
\text { Laboratory } \\
\\
1 \\
\end{array}$} & \multirow[t]{2}{*}{$\begin{array}{l}\text { Liczba próbek } \\
\text { poddanych } \\
\text { analizom } \\
\text { Samples tested } \\
2\end{array}$} & \multicolumn{2}{|c|}{$\begin{array}{c}\text { Wyniki identyfikacji na podstawie cech } \\
\text { morfologicznych - } \\
\text { gatunek i liczba próbek } \\
\text { Results of identification } \\
\text { based on morphological features - } \\
\text { species and the number of samples }\end{array}$} & \multicolumn{2}{|c|}{$\begin{array}{l}\text { Wyniki identyfikacji przy użyciu } \\
\text { testów molekularnych - gatunek } \\
\text { i liczba próbek } \\
\text { Results of identification } \\
\text { with molecular tests - } \\
\text { species and the number of samples }\end{array}$} \\
\hline & & 3 & 4 & 5 & 6 \\
\hline $\begin{array}{l}\text { Laboratorium Wojewódzkie } \\
\text { w Bydgoszczy } \\
\text { Voivodeship Laboratory } \\
\text { in Bydgoszcz }\end{array}$ & 122 & $\begin{array}{l}\text { Globodera rostochiensis } \\
\text { G. artemisiae }\end{array}$ & $\begin{array}{c}111 \\
11\end{array}$ & $\begin{array}{l}\text { G. rostochiensis } \\
\text { G. artemisiae }\end{array}$ & $\begin{array}{c}111 \\
11\end{array}$ \\
\hline $\begin{array}{l}\text { Laboratorium Wojewódzkie } \\
\text { w Koszalinie } \\
\text { Voivodeship Laboratory } \\
\text { in Koszalin }\end{array}$ & 24 & G. rostochiensis & 24 & G. rostochiensis & 24 \\
\hline $\begin{array}{l}\text { Laboratorium Wojewódzkie } \\
\text { w Poznaniu } \\
\text { Voivodeship Laboratory } \\
\text { in Poznań }\end{array}$ & 50 & G. rostochiensis & 50 & G. rostochiensis & 50 \\
\hline $\begin{array}{l}\text { Laboratorium Wojewódzkie } \\
\text { w Pruszczu Gdańskim } \\
\text { Voivodeship Laboratory } \\
\text { in Pruszcz Gdański }\end{array}$ & 117 & G. rostochiensis & 117 & G. rostochiensis & 117 \\
\hline $\begin{array}{l}\text { Centralne Laboratorium } \\
\text { w Toruniu } \\
\text { Central Laboratory in Toruń }\end{array}$ & 271 & $\begin{array}{l}\text { G. rostochiensis } \\
\text { G. artemisiae } \\
\text { G. pallida } \\
\text { wynik niejednoznaczny - } \\
\text { z przewagą cech G. rostochiens } \\
\text { vague result - predominating } \\
\text { characters of } G \text {. rostochiensis }\end{array}$ & $\begin{array}{c}246 \\
24 \\
1 \\
1\end{array}$ & $\begin{array}{l}\text { G. rostochiensis } \\
\text { G. artemisiae } \\
\text { G. pallida }\end{array}$ & $\begin{array}{c}246 \\
24 \\
2\end{array}$ \\
\hline
\end{tabular}




\begin{tabular}{|c|c|c|c|c|c|}
\hline 1 & 2 & 3 & 4 & 5 & 6 \\
\hline $\begin{array}{l}\text { Łącznie } \\
\text { Total }\end{array}$ & 584 & $\begin{array}{l}\text { G. rostochiensis } \\
\text { G. artemisiae } \\
\text { G. pallida } \\
\text { wynik niejednoznaczny - } \\
\text { z przewagą cech G. rostochiens } \\
\text { vague result - predominating } \\
\text { characters of } G \text {. rostochiensis }\end{array}$ & $\begin{array}{c}547 \\
35 \\
1 \\
1\end{array}$ & $\begin{array}{l}\text { G. rostochiensis } \\
\text { G. artemisiae } \\
\text { G. pallida }\end{array}$ & $\begin{array}{c}547 \\
35 \\
2\end{array}$ \\
\hline
\end{tabular}

W jednym przypadku nie była możliwa jednoznaczna identyfikacja z zastosowaniem metody morfologicznometrycznej ze względu na to, że cysty wykazywały zarówno cechy charakterystyczne dla $G$. rostochiensis, jak i $G$. pallida, z przewagą cech $G$. rostochiensis. Za przynależnością do gatunku G. rostochiensis przemawiały następujące cechy: morfologia i wymiary cyst (średnica okienka, odległość okienka od odbytu, indeks Graneka, liczba fałdów oskórka między okienkiem a odbytem) (rys. 3) oraz wymiary osobników młodocianych (długość ogona i przezroczystej części ogona). Jednak długość sztyletu oraz szerokość guzików sztyletu wskazywały w większym stopniu na gatunek G. pallida, natomiast kształt guzików charakteryzował się dużą zmiennością. Notowano zarówno guziki drobne i zaokrąglone o budowie charakterystycznej dla gatunku $G$. rostochiensis, jak i takie, których przednia powierzchnia była lekko wgłębiona (rys. 3), co wskazywało na gatunek G. pallida). Wynikiem reakcji PCR według Bullmana i Marshalla (1997) był produkt o wielkości 266 pz (rys. 4), a reakcji PCR według Zouhara i wsp. (2000), produkt o wielkości 391 pz (rys. 5). Reakcja PCR-RFLP dla trawienia restrykcyjnego enzymem Bsh1236I według Thiery i Mugniery (1996), dała produkty reakcji 1200 pz dla PCR i $\sim 500$, $\sim 400, \sim 350, \sim 190$ pz (rys. 6) po trawieniu produktu reakcji PCR, co pozwoliło na jednoznaczną identyfikację badanych nicieni do gatunku G. pallida.

Dane literaturowe również wskazują zmienność wewnątrzgatunkową u G. rostochiensis i G. pallida odnoszącą się zarówno do cech morfologicznych, jak i najistotniejszych wymiarów cyst oraz osobników młodocianych (Subbotin i wsp. 2010). Na przykład, u gatunku G. pallida guziki sztyletu mogą mieć kształt od zwężonych w szczytowej części, przypominających kotwicę, po niewielkie, zaokrąglone, przypominające guziki G. rostochiensis (Savotikov i Smetnik 1995).

Sekwencjonowanie fragmentu rDNA wyizolowanego z cyst zidentyfikowanych jako G. pallida oraz jego analiza porównawcza prowadzona in silico wskazały na podobieństwo na poziomie 89-95\% w przypadku materiału pochodzenia cypryjskiego (Karnkowski i wsp. 2011) oraz 97\% w przypadku materiału pochodzenia krajowego z sek- wencją rDNA kilkunastu izolatów G. pallida zdeponowanych w Banku Genów Narodowego Centrum Informacji Biotechnologicznej (NCBI).

\section{Wnioski / Conclusions}

1. Badania wykazały, że na terenie Polski na ziemniaku występuje głównie gatunek G. rostochiensis, natomiast G. pallida jest notowany sporadycznie.

2. Badania $\mathrm{z}$ zastosowaniem metod molekularnych potwierdziły wyniki identyfikacji nicieni $\mathrm{z}$ rodzaju Globodera do gatunku metodą mikroskopową (morfologiczno-metryczną).

3. U cyst $G$. rostochiensis cechy morfologiczne i najważniejsze wymiary charakteryzowały się znacznie mniejszą zmiennością niż w przypadku G. pallida. Jeśli nawet istniały wątpliwości odnośnie przynależności cyst w oparciu o ich cechy morfologiczne cyst, analiza cech morfologicznych osobników młodocianych pozwoliła na jednoznaczną ich identyfikację do gatunku.

4. Przeprowadzone badania wykazały, że zastosowanie metod molekularnych do identyfikacji cyst mątwików jest niezbędne w przypadkach, gdy cysty nie są typowe, bądź wykazują cechy z pogranicza gatunków, a wynik identyfikacji morfologiczno-metrycznej nie jest jednoznaczny. Jednocześnie potwierdziły one, że nie ma konieczności badania metodami molekularnymi wszystkich typowych cyst G. rostochiensis. Generalnie w typowych przypadkach nie ma również niebezpieczeństwa błędnej identyfikacji cyst z gatunku G. artemisiae i pomylenia ich z mątwikami tworzącymi cysty na ziemniaku.

\section{Podziękowanie / Acknowledgements}

Autorzy pragną podziękować ANSES, Laboratoire de la Santé des Végétaux, w Le Rheu (Francji) za udostępnienie metodyki identyfikacji $G$. artemisiae oraz konsultacje w tym zakresie.

\section{Literatura / References}

Brzeski M.W. 1998. Nematodes of Tylenchina in Poland and Temperate Europe. Muzeum i Instytut Zoologii PAN, Warszawa, 398 pp. Bulman S.R., Marshall J.W. 1997. Differentiation of Australasian potato cyst nematode (PCN) populations using the polymerase chain reaction (PCR). New Zealand Journal of Crop and Horticultural Science 25 (2): 123-129. 
Dobosz R., Budziszewska M., Nowaczyk K., Obrępalska-Stęplowska A. 2013. Diagnostyka nicieni pasożytów roślin objętych przepisami kwarantanny. Instrukcja rozpoznawania gatunków z rodzaju Globodera. Wyd. II. Instytut Ochrony Roślin - Państwowy Instytut Badawczy, Poznań, 24 ss.

Karnkowski W. 2006. Nicienie podlegające obowiązkowi zwalczania - wykrywanie i oznaczanie. GIORiN, Warszawa, 165 ss.

Karnkowski W., Dobosz R., Kaczmarek A., Obrępalska-Stęplowska A., Kierzek D. 2011. Wystąpienie mątwika agresywnego Globodera pallida (Stone, 1973) Behrenn 1975 (Nematoda: Heteroderidae) w dwóch przesyłkach ziemniaków jadalnych sprowadzonych do Polski z Cypru. [Occurence of the white potato cyst nematode Globodera pallida (Stone, 1973) Behrens, 1975 (Nematoda, Heteroderidae) in two consignments of table potatoes moved to Poland from Cyprus]. Progress in Plant Protection/Postępy w Ochrony Roślin 51 (4): 1545-1549.

Karnkowski W., Kaczmarek A., Dobosz R., Wieczorek P., Obrępalska-Stęplowska A. 2012. Wystąpienie mątwika agresywnego Globodera pallida (Stone, 1973) Behrens 1975 (Nematoda: Heteroderidae) na terytorium Polski. [Occurence of the white potato cyst nematode Globodera pallida (Stone, 1973) Behrens, 1975 (Nematoda, Heteroderidae) on the territory of Poland]. Progress in Plant Protection/Postępy w Ochronie Roślin 52 (4): 1087-1092.

Kornobis S., Stefan K. 1991. Plant parasitic nematodes as pests of potatoes in Poland. Bulletin OEPP/EPPO Buletin 21 (1): 331-334.

OEPP/EPPO 2009. EPPO Standards. PM 7/40(2) Globodera rostochiensis and Globodera pallida. Bulletin OEPP/EPPO Bulletin 39 (3): 354-368.

OEPP/EPPO 2013. EPPO Standards. PM 7/40(3) Globodera rostochiensis and Globodera pallida. Bulletin OEPP/EPPO Bulletin 43 (1): 119-138.

Savotikov Yu.F., Smetnik A.I. 1995. Spravočnik po vreditelam bolezniam rastienij i sorniakam imiejuščim karantinnoje značenije dla territorii Rossijskoj Federacii. Arnika Nižni Novgorod, 232 ss.

Subbotin S.A., Mundo-Ocampo M., Baldwin G.B. 2010. Systematics of cyst nematodes (Nematoda: Heteroderinae). Nematology Monographs \& Perspectives 8A: 107-177.

Thiéry M., Mugniéry D. 1996. Interspecific rDNA restriction fragment length polymorphism in Globodera species, parasites of solanaceous plants. Fundamental and Applied Nematology 19: 471-479.

Zouhar M., Rysanek O., Kocova M. 2000. Detection and differentiation of the potato cyst nematodes Globodera rostochiensis and Globodera pallida by PCR. Plant Protection Science 36: 81-84. 